\title{
THE ORIGIN AND THE USE OF THE WORD HERPES*
}

\author{
by \\ T. S. L. BESWICK
}

THE word 'herpes' has been used in medicine for at least twenty-five centuries. However, its meaning has changed considerably during this time. Indeed, as Hebra ${ }^{58}$ has pointed out, 'in the attempt to give an historical account of Herpes ..., we meet with almost insurmountable difficulties'. Possibly none of the conditions which we designate herpes today would have been called by that name in the time of Hippocrates, although the word itself was already well known as a medical term.

The word $\varepsilon \varrho \pi \eta \varsigma$, derived from the verb $\varepsilon \rho \pi \varepsilon \imath$ (=to creep), was originally applied to spreading cutaneous lesions, usually ulcerative, such as skin cancer, lupus vulgaris, noma, erysipelas, ringworm, eczema and, perhaps, smallpox. Most of these are conditions, it must be allowed, to which the epithet 'creeping' is far more apposite than it is to any of the conditions which we know as herpes today.

To the authors of the Hippocratic Corpus, 'herpes' was usually a serious condition and the word probably denoted a type of lesion rather than a disease

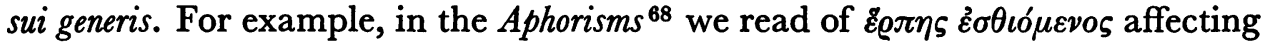
the anus, genitalia, uterus, and bladder. Again, in Epidemics III ${ }^{67}$ mention is

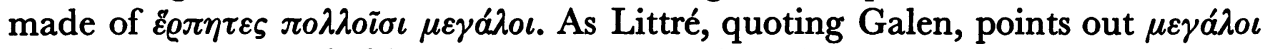
in this context probably means severe rather than large: indeed Willan ${ }^{119}$ considers that this passage may refer to smallpox. ${ }^{\circ} E \varrho \pi \eta \varsigma ~ \varepsilon \sigma \sigma \theta \iota o ́ \mu \varepsilon v \varsigma \varsigma$ is also mentioned in The Use of Liquids ${ }^{71}$ where we read that warm water is valuable in its treatment.

The word occurs in the Prorrhetics and in the Coan Prognostications, both works which many scholars and commentators, including Littré, have regarded as older than Hippocrates himself. In Prorrhetics II $^{72}$ it is stated that of all serpiginous ulcers ('. . . his quae despascendo serpunt', Föes) ${ }^{34}$ herpes is the least dangerous but the hardest to cure, resembling cancer in this respect. Surely this must be lupus vulgaris, ringworm, or perhaps eczema, rather than anything we should call herpes.

The Coan Prognostications 70 described a kind of 'herpes', starting above the groin and spreading towards the flank and the pubes, which indicates a disordered state of the abdomen. This condition could, of course, have been herpes zoster. Föes has no real justification for translating हैe $\tilde{\eta} \eta \tau \varepsilon \zeta$ as 'serpentia ulcera' except that it makes better sense than would 'zona' in the other contexts in which the word is used in Hippocrates. It is also perhaps significant that shingles, which is not a very uncommon condition, is not recognizably described

* Based on fart of a thesis submitted for the degree of M.D. at the University of Cambridge. 


\section{T. S. L. Beswick}

anywhere else in the Hippocratic Corpus. However it is surprising that, if herpes zoster of the lower thoracic nerve roots was recognized, the probably commoner herpes zoster of the upper thoracic nerve roots is not described as well. One can only conclude that if the condition we call herpes zoster was called herpes in the time of Hippocrates, it was certainly not the only, or even the usual, condition to be so designated.

What is perhaps the most interesting passage in the Hippocratic Corpus, and certainly the most tantalizing, occurs in Epidemics II. This book is regarded by most authorities as later than Epidemics I and III, and not by Hippocrates himself. As Littré ${ }^{80}$ pointed out the available manuscript versions are manifestly imperfect; indeed, he has so emended the text that what appears in Föes ${ }^{36}$ as the account of a single case, that of Zöile, appears in Littré as the accounts of two separate cases. Towards the end of the passage, which as Littré would have it, describes two cases of pneumonia with otitis media, there is reference to what might have been the lesions of herpes febrilis. In Föes ${ }^{36}$ the words used

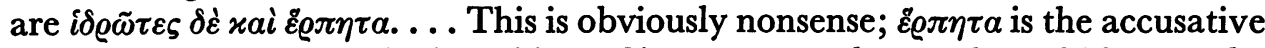
singular. As the phrase is the subject of its sentence, the word would have to be

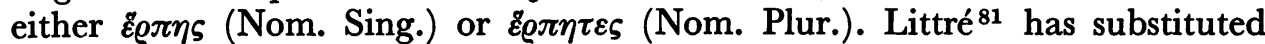

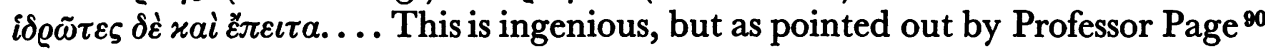
is not much better. The word xai is now redundant and if present in the original could only have served to emphasize $\ddot{\varepsilon} \pi \varepsilon i \tau \alpha$ which in this context needs no special emphasis. Further, as Professor Page says, it is most improbable that any scribe would have written $\varepsilon \varrho \pi \eta \tau \alpha$ which is not a very common word, and nonsense in this context, in place of the very common $\ddot{\pi} \tau \varepsilon \varepsilon \tau a$. The reverse error is much more probable, but as has already been emphasized the original text could not have contained the word ह̋o $\tilde{\tau} \tau \alpha$. He suggests that here we are dealing

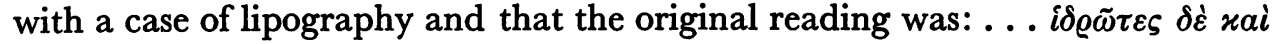

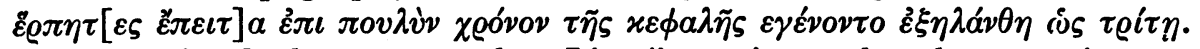

This makes far better sense than Littrés version and at the same time enables us to retain the word ह̋ $\varrho \tau \eta \tau$-without having to accept Föes's accusative singular.

Unfortunately, even if Professor Page's arguments be accepted, we cannot be absolutely certain that the condition described was herpes simplex. We are merely told that the 'lesions' occurred on the head ( $\varkappa \varepsilon \phi a \lambda \tilde{\eta} s)$ for a long time and dried up on the third day. It is difficult to reconcile the statements 'for a long time' and 'dried up on the third day', unless the implication is that, although the individual lesions dried up in two or three days, new lesions or crops of lesions continued to appear for much longer than that: but if this was in fact the author's meaning, his expression of it leaves much to be desired. Another

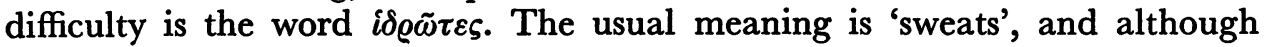
sweating confined to the head is now well recognized ${ }^{10}, 77$ it usually follows injury to the peripheral nerves, especially that due to suppurative infections of the parotid, or is associated with disease of the spinal cord such as syringomyelia, and it is usually precipitated by eating or drinking (Gustatory hyperhidrosis). It is difficult to see why in this case the sweating should be of this type, unless the suppurative condition of the ear referred to was parotitis and not otitis 


\section{T. S. L. Beswick}

media. This is possible, although we are clearly told that the pus was discharged from the ear.

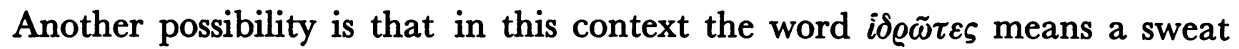
rash and not merely sweating: however, the usual Greek word for a sweat rash is $i \delta \omega \omega$.

In spite of Professor Page's admirable emendation of the text, this passage must unfortunately remain something of a mystery: we cannot be certain that the Coan Physicians described 'fever blisters' as 'herpes'.

That herpes febrilis was quite familiar to them is clear, however, from a passage in Epidemics VI ${ }^{69}$ which describes ulceration of the lips in intermittent fevers. It is noteworthy that von Bärensprung ${ }^{11}$ still clung to the view expressed in this passage that herpes febrilis occurs only in intermittent and not in continous fevers, a view which as $\mathrm{Hebra}^{63}$ points out is quite unjustified.

There is definite evidence, however, that after Hippocrates the Greeks did call shingles 'herpes'. Scribonius Largus ${ }^{104}$ has the phrase 'zonam quam Graeci ह̊o $\eta \eta \tau \alpha$ dicunt'. His contemporary Pliny (the Elder) ${ }^{96}$ gives a recognizable account of the shingles, which he calls 'zoster' so that it is evident that herpes zoster was well known in the first century A.D. and probably not unreasonable to regard the 'zona' of Scribonius as the same as the 'zoster' of Pliny. It is of interest to remark that Pliny records the belief that if the lesions of herpes zoster extend right round the body, the condition is fatal. He regards shingles, as do many later authors, as a species of erysipelas.

Aemilius Macer, writing in the first century B.c., has two references to herpes. In one, where he speaks of the virtues of the house-leek, also recommended by Pliny, he states 'hac fugit apposita sacer ignis, et herpeta mordax' ${ }^{4}$ In the other, which refers to the value of rue, he has the passage:

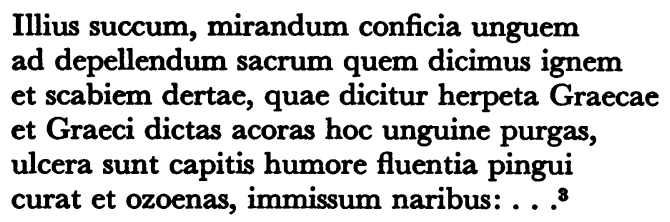

While these two passages do not provide much evidence to suggest what exactly the writer meant by the word 'herpes', they make it clear that he regarded 'herpes' and 'ignis sacer' as distinct, although perhaps related, conditions.

This is important because the passage in Celsus ${ }^{19}$ which deals with ignis sacer has often been held to refer to herpes zoster. There would appear to be no justification for this view except the phrase 'fit maxime in pectore, aut lateribus'. But even if herpes zoster were one of the conditions comprehended by the term 'ignis sacer', it can scarcely have been the main one. Herpes zoster can hardly be said to occur 'especially on the soles of the feet' ('praecipueque in plantis')!

Certainly other Latin authors used the term 'ignis sacer' to describe conditions far more severe than zoster. In many cases it appears to have been an epidemic disease: for example, in Virgil, ${ }^{116}$ Seneca, ${ }^{105}$ and Lucretius. ${ }^{84}$

In the previous section (Sect. 3) Celsus deals with $\theta \eta \varrho^{\prime} \omega \mu \alpha$ and describes a 216 
deep spreading ulcer, eroding even the bones, which may arise as a complication.

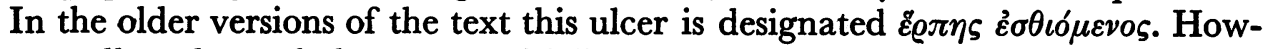
ever all modern scholars agree with Leonardi Targa ${ }^{110}$ that the correct reading

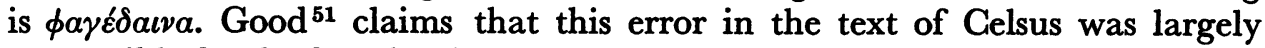
responsible for the fact that later writers applied the term 'herpes' to conditions in which ulceration involved not only the skin, but the deeper tissues as well. In Good's opinion the older Greek and Latin writers understood by the word only superficial, spreading cutaneous lesions. It is impossible to sustain this argument.

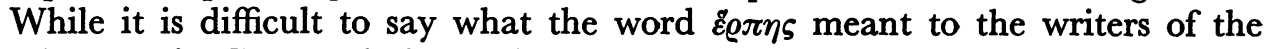
Hippocratic Corpus, it is nowhere expressly stated that the term was only applicable to superficial conditions. Indeed, the reference already cited to herpes of the uterus and bladder seems to make it clear that such was not the case. Further, it seems probable that Celsus exerted little influence on medical writers after his time until his surviving works were printed at Florence in 1478 from manuscripts discovered a few years earlier by Pope Nicholas $V^{54}$ ( $1379^{-}$ 1455). Nevertheless Saliceto ${ }^{99}$ writing in 1275 , tells us that although herpes was commonly called 'erysipelas' by the laity, 'herpes' can be distinguished from true 'erysipelas' by the fact that 'erysipelas' involves only the skin whereas in 'herpes' the underlying tissues, including even the bone, are involved. It is of course impossible to be certain that Saliceto had no direct or indirect access to Celsus, but it seems probable that this passage expressed the prevailing view of the surgeons of his time.

Celsus ${ }^{20}$ gives quite a good account of aphthous ulcers in the mouth and draws attention to the fact that they may be dangerous in children, especially those still at the breast. Surely some of the cases he had in mind when he wrote this must have been primary herpetic stomatitis.

Whether errors in the available texts of Celsus were responsible to any extent for the great differences between the meanings which later writers attached to the word 'herpes' is questionable. What cannot be disputed, however, is that Galen, who had far more influence on medieval and Renaissance medical writers than Celsus, did nothing to clarify the situation. Galen uses the word repeatedly, but either he was hopelessly confused as to its proper meaning or his views on its meaning changed with time. In the Definitiones 49 'herpes' is defined as an ulcer and, a few lines lower down as a 'creeping', superficial ulceration of the skin. But elsewhere he states: 'herpes is not always an ulcer' ${ }^{45}$ In this passage, too, we learn that herpes is the same kind of condition as cancer and phagedaena. In a much-quoted passage ${ }^{\mathbf{4 1}}$ he begins by saying that 'herpes' and 'erysipelas' are

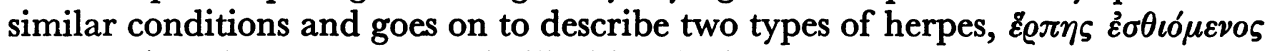
(exedens) and $\varepsilon \rho \pi \eta \varsigma$ x $\gamma \chi \varrho i a s$ (miliaris). The latter condition, he avers, was not recognized by Hippocrates but was described by later writers.

In another work ${ }^{47}$ the two types are again referred to and we are told that

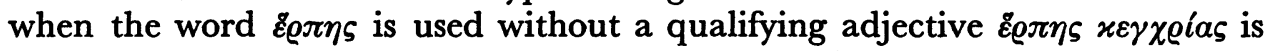

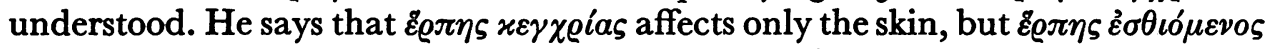
is a more severe condition in which there is ulceration, not only of the skin, but of the deeper tissues as well. This statement is contradicted by his statement ${ }^{48}$ 


\section{T. S. L. Beswick}

that only those ulcers which affect the skin alone are called $\varepsilon \varrho \pi \eta \varsigma$ those

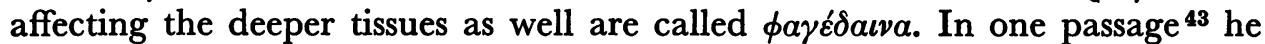
groups together 'carbuncle', 'erysipelas', 'herpes', and 'gangrene', because in all of them there is an alteration from the natural colour of the affected part. The same grouping, except that 'cancer', 'oedema', and 'phagedaena' are added, also occurs elsewhere: ${ }^{44}$ this time they are grouped together because the aetiology and pathogenesis are the same. In a third passage ${ }^{42}$ 'herpes' and 'cancer' are singled out for special mention because both sometimes are and sometimes are not associated with ulceration.

It is obvious, without quoting further, that Galen can be made to provide authority for attaching the name 'herpes' to almost any ulcerative condition of the skin, whether or not deeper tissues are involved, as well as to some nonulcerative skin lesions. Certainly there is nothing to suggest that the use of the word zej $\eta \varsigma$ by Galen necessarily implied that the lesion so designated consisted of vesicles or bullae on the skin. Hebra, ${ }^{59}$ it is true, states that Galen described a

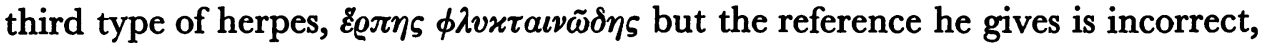
and I have been unable to confirm his statement. No other writer familiar to me says definitely that Galen described more than two types, except Ambroise Paré. ${ }^{92}$ The latter author, however, has misinterpreted his authority ${ }^{47}$ believing that Galen regarded herpes without a qualifying adjective as different from herpes miliaris. Paré does not mention herpes phlyctaenodes.

Galen, and with him most subsequent writers up to comparatively recent times are consistent in their views on the pathogenesis of whatever lesion they may designate 'herpes'. 'Herpes' is due to the excretion or attempted excretion of acrid waste matter by the skin, which is either eroded or raised up to form vesicles or bullae (Galen, ${ }^{46}$ Gorraeus ${ }^{53}$ and Sennert ${ }^{106}$ ). The material being excreted is, according to most authors, either bile alone (herpes miliaris) or bile mixed with other humours (herpes exedens).

Oribasius ${ }^{89}$ quotes Galen almost verbatim and adds that herpes miliaris is so called because it 'produces' excrescences like grains of millet on the skin.

Aetius of Amida ${ }^{6}$ also follows Galen, but elsewhere ${ }^{5}$ he quotes Herodotus (the physician) who gives a very good account of herpes labialis, although he does not call it 'herpes', and notes that it heralds the termination of a fever. This is probably the oldest surviving reference to the view that fever blisters are of good prognostic omen in febrile disorders; a view contemptuously dismissed by $\mathrm{Hebra}^{64}$ but recently shown to have some foundation, at least in pneumonia. ${ }^{109}$

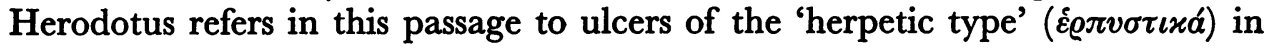
fevers.

Paulus Aegineta ${ }^{93}$ also describes the two types of herpes and quotes Oribasius. His account is not very detailed but the commentary on this passage by the translator ${ }^{2}$ is valuable. Paulus describes an application for the treatment of 'herpes phlyctaenodes' but does not attempt to identify the condition.

The Arabic writers mainly followed Galen in recognizing the two types, but added a third, known as 'Persian fire'.2, 118 The exact nature of this latter condition is unknown, but Guy de Chauliac ${ }^{21}$ tells us that 'Persian fire' and 'Sacred 


\section{The Origin and the Use of the Word Herpes}

fire' are both synonyms for carbuncle, of which he gives an adequate description. It is of interest that according to Willan ${ }^{118}$ one of the Arabic words for herpes, 'nemlet' means literally 'the ant', because 'formica', 'formy', and 'fourmi' persisted during the Middle Ages, especially in France, as names for erysipelas and herpes.

The Arabic writers themselves give a rather different account of 'Persian fire'. Haly Abbas ${ }^{55}$ says 'Livid vesicles, with an irregular base and confluent, resembling the effects of a burn, and intermixed with puffy tumours, are called Persian fire, and constitute the worst kind of Smallpox.' The translation is Willan's. Constantinus Africanus, ${ }^{23}$ it is to be remarked, gives very much the same description, but calls the condition 'ignis sacer'.

Avicenna ${ }^{9}$ observes that 'anthrax' and 'Persian fire' are closely allied. The latter, 'which partakes of the nature of herpes', is accompanied by violent, malignant, and fatal fever, and occurs in pestilential seasons.

Willan ${ }^{120}$ believed that the Arabic writers were referring to smallpox when they used the term 'Persian fire'.

Actuarius (John Zachary), a Byzantine author of uncertain date, but probably of the twelfth or thirteenth century, appears to be the first author who can be said definitely to have applied the term 'herpes' to cutaneous ringworm. His probable date is ably discussed by Freind. ${ }^{40}$ Actuarius says, in the Latin trans-

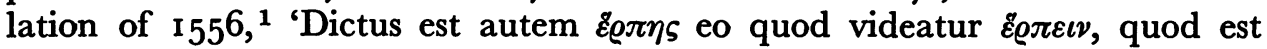
serpere per cutem summam, . . .; and goes on to give a description which is clearly that of ringworm of the skin. He also contradicts Galen as to the meaning of the word 'herpes' without a qualifying adjective: Actuarius, having defined 'herpes' as an ulcerative condition involving the skin and the subcutaneous tissue, describes E̊ pustules on the surface of the skin.

From the tenth to the beginning of the eighteenth centuries 'herpes' seems to have been a word used far more by surgeons than by physicians. Perhaps 'herpes exedens' was regarded as the most important kind of herpes and, like Turner, ${ }^{115}$ physicians felt that, 'this latter more properly belonging to a discourse of ulcers', they should leave 'the same to be dealt with in surgical writers'. Saliceto and Ambroise Paré have already been mentioned. Guy de Chauliac ${ }^{22}$ describes herpes as a species of erysipelas. He says that there are two kinds of erysipelas called by Avicenna 'spina' and 'formica'. A few lines further on he states that 'formica' and 'herpes' are the same condition, and that whereas 'formica' is associated with ulceration, 'spina' is not. Theodoric ${ }^{112}$ ( $1205-98$ ) speaks of 'herpes' or 'formica' in much the same terms.

Jean Fernel ${ }^{32}$ comes closer than previous writers to our modern concept of herpes when he says: 'His proxima est papula. Est autem ardem cutem serpentibus minimis pustulis exasperans ac rodens, Graecis Herpes appelatur.' Nevertheless he recognizes that 'herpes' can be an unpleasant condition, for he continues: 'Ea quidem duplex, una simplex quae herpes est miliaris, altera fera quae herpes exedens nuncupatur.' He points out that the differential diagnosis between 'herpes' and 'erysipelas' may be difficult but claims that 


\section{T. S. L. Beswick}

'herpes' is a less severe condition than 'erysipelas'. This is the opposite of Saliceto's view.

Gorraeus ${ }^{53}$ was clearly in difficulties when he came to write of 'herpes'. He first tries to follow Galen and defines the condition as an 'ulcerated tumour' proceeding from an excess of bile. He recognizes three types: 'herpes esthiomenos', of which he says, 'totam cutem usque ad carnem subjectam exulcerat'; 'herpes miliaris' and 'herpes phlyctenodes' (the spelling is his). Of the two latter types he says 'superficiem solum velut inurit, appellaturque simpliciter ह̋ej $\eta \varsigma^{\prime}$. He wisely does not attempt to fit the 'zona' of Scribonius Largus into this scheme. He merely adds: 'Caeterum E̊ apud Scribonium Largum intelligitur, ut Cap. 62. Est autem zona ignis sacri species quae medium hominem ambit cingitque, dicitur alio nomine $\zeta \omega \sigma \tau \eta \varrho^{\prime}$.'

Another surgeon, Fabricius Hildanus ${ }^{66}$ describes herpes exedens of the leg occurring as a complication of some mild inflammatory condition of the foot. He says: 'tandem vero herpes exedens totum crus invasit, idque, adeo vehementer, ut chirurgi de abscissione tibiae cogitarent, sequidem ea in genu fieri potuisset'. This is clearly no trivial skin disorder.

Petrus Forestus ${ }^{37}$ in his book De Lue Venerea speaks of 'herpetes' on the face and elsewhere in syphilis. He gives information about treatment but no other details: presumably he supposed that his readers would be familiar with the condition.

Nicolaus Tulp, ${ }^{114}$ under the heading 'Exedens, praecordiorum herpes', gives an account of what is obviously zoster. He cites Pliny and says that the condition is of the same kind as 'ignis sacer'. He says that the underlying tissues may be involved as well as the skin but does not particularly stress this.

Daniel Sennert ${ }^{106}$ emphasizes the fact that 'herpes' and 'erysipelas' are similar conditions and have a similar aetiology. He has three types: ' $\mathrm{H}$. simplex' ('Herpes vero solam cutem exulcerat'), ' $H$. miliaris' ('qui vesiculas in cute similes milio excitat'), and ' $\mathrm{H}$. esthiomenos' or ' $\mathrm{H}$. exedens', which is the 'herpes' of Galen. In this latter view he was, of course, mistaken. Galen ${ }^{47}$ expressly states that the word 'herpes' without an adjective is to be understood as meaning 'herpes miliaris'.

Richard Morton ${ }^{88}$ describes what can be definitely identified as herpes febrilis, although he does not specify the usual site of the eruption. He stresses the association with febrile conditions and adds that fevers accompanied by 'herpes' are always the mildest and always benign.

Boerhaave ${ }^{16}$ mentions 'Herpes' in that section of his Aphorisms which deals with rickets, but it is difficult to know what he meant by the term. He expresses the common view that cutaneous eruptions should not be suppressed by overvigorous treatment since by so doing the physician may convert a relatively benign skin disease into a severe internal disorder. This view was based on the theory that most skin eruptions represent the excretion by the body of noxious waste matter and if the excretion is prevented the waste matter will accumulate within the body and result in some more serious disturbance of the patient's health.

Van Swieten ${ }^{108}$ in his commentary on this passage makes it quite clear that 


\section{The Origin and the Use of the Word Herpes}

he believes that the condition to which Boerhaave refers is infantile eczema, and goes on to give an excellent account of that disorder, one stage of which, he says, is called 'Herpes miliaris' or 'Herpes ficosus'.

Hoffmann, ${ }^{74}$ under the term 'scabiei herpetis miliaris', describes a condition comprising small papules or pustules on the skin, which rapidly heal by drying up and forming small flakes (squamuli) which fall off. He says that the condition may occur at various sites, such as the feet, thighs, hands, scrotum, and perinaeum, and is very liable to recur. Irritation is always a prominent feature. There can be little doubt that the main condition he was describing was eczema, although he would no doubt have used the term to embrace other conditions as well. $\mathrm{He}$ completes his description by referring to a variety in which there are no evident papules or pustules but in which the irritation is even more intolerable. This variety is observed especially in the elderly and occurs on the scrotum, perinaeum, and round the anus. In the latter situation the condition may be associated with the presence of haemorrhoids. A better description of senile pruritus could hardly be demanded.

Hoffmann's description of herpes exedens, although he avers that it is the herpes of Hippocrates and the ignis sacer of Celsus, and that the underlying tissues are eroded as well as the skin, sounds otherwise like pustular ringworm. $\mathrm{He}$ regards it as related to erysipelas.

He deals with 'zona ignea' in another section of the same chapter. His description is worth quoting in full: 'quando autem herpes mali moris pectus speciatim et praecordia occupat cum cardialgia, calore praenaturali, pruritu, cutis inflammatione, pustulisque parvis et lucidus instar cinguli ad manus latitudinem in pectore dispersis, adfectus vocatur zona ignea. ... Then follow references to Severinus, Tulp, Schultz, and Langius.

Daniel Turner, ${ }^{115}$ although earlier in date than Hoffmann, is much more modern in his views on herpes, as will be evident from the following quotations from his work:

The herpes is a choleric pustule breaking forth of the skin diversely, and accordingly receiving a diverse denomination.

If they appear single, as they do often in the face, they arise with a sharp top and inflamed base; and having discharged a drop of the matter they contain, the redness and pain go off and they dry away of themselves.

There is another sort partaking of greater corrosion and malignity arising several of them in a round ring, as it were, with smart and sometimes great itching. This being called serpigo, by the common people tetter or ringworm . . . by Celsus Ignis sacer, although by this latter I rather think is meant the erysipelas, an offspring of the same choleric humour. The tetter is a small cluster of pustules, seizing the face, hands, or other parts, of a rebellious sometimes, an obstinate nature, eating in the skin and spreading its taint frequently to a larger compass, forsaking the old place and seizing the adjacent parts. It neither matures nor comes to digestion; but being rubbed will sometimes gleet a thin sharp water, tho' oftener not, ... .

There is another species of this disease, appearing in larger heaps of small pustules upon several parts of the body as the neck, breast, loyns, hips and thighs; these are usually attended with a light fever and inflammation round about them, and rising up with white mattery heads, there succeeds a small round scab, resembling the millet seed, from which the disease has borrowed the name of herpes milaris, being the same with that our people call shingles. 


\section{T. S. L. Beswick}

Again there is yet another sort, which from its greater degree of virulence and corrosion is called by the Greeks herpes esthiomenos ... . it is usually known as herpes exedens vel depascens; but this latter more properly belonging to a discourse of ulcers, leaving the same to be dealt with in surgical writers, we shall treat of the other three.

Turner thus gives us the first adequate description of herpes simplex under its modern name, stressing its predilection for the face and its short, self-limiting course. He also recognizes zoster as a species of herpes. He was probably mistaken in his view that the 'herpes miliaris' of earlier writers was zoster. It will be observed that he regards ringworm as a species of herpes, a view that was to prevail until after the middle of the nineteenth century, and he recognizes the existence of 'herpes exedens', although he regards it as a surgical condition and declines to discuss it.

The latter half of the eighteenth century saw the rise of the medical nosologists. These writers have been somewhat neglected by medical historians, nevertheless they made a useful contribution to medicine. Their initial premises were sound. They recognized that unless the meaning of words was accurately defined and the definitions universally accepted, progress in medicine, as in the other sciences, was bound to be seriously impeded; and they accepted the rule of the botanists and the zoologists that, as far as possible, a word should bear the meaning assigned to it by the first author to employ it as a technical term. Although perfectly sound, this second proposition led to endless confusion and controversy. Many medical terms had been in use for so long that their original meaning was often a matter for pure guesswork. Even if many of their conclusions were mistaken and their systems have been forgotten, they undoubtedly did much to put medical terminology on a sound footing and drew the attention of doctors to the importance of using medical terms as instruments of precision.

The principal nosological systems of his predecessors are conveniently summarized by Cullen ${ }^{25,}{ }^{26}$ in his Synopsis Nosologiae Methodicae, although reference to the original works from which he quotes is necessary to determine the individual species within the various genera. The first in the field was de Sauvages who published a small book, Traité des Classes des Maladies as early as I731. When Linnaeus saw a copy of this book in the house of a physician in Leyden he at once discerned a kindred spirit and initiated a correspondence with de Sauvages which lasted for thirty years, although, as far as is known, the two never met..$^{30}$ De Sauvages published the first edition of his main work, Nosologia Methodica sistens Morborum Classes, ${ }^{102}$ in January $1764 .^{*}$ De Sauvages sought to carry on the work of identifying and classifying diseases by the study of their natural history started by Sydenham. However, his list of about 2400 species is more a list of symptoms than of diseases. In his classification of skin diseases he was influenced by Sennert and Daniel Turner. His genus 'Herpes' contains seven species one of which $\mathrm{H}$. Periscelis, includes zoster. Later, in 1768 ,

\footnotetext{
* There is some confusion about the date of first publication of de Sauvages's Nosologia. Major ${ }^{85}$ and Pagel191 give the date as 1760 and it is possible that some copies of the first one or two volumes may have been issued bearing that date. However, the full five volume work was printed in Lyons and published in 1764 in Lyons and Amsterdam, although the title-page bears the date 1763 . For a full discussion, see Berg. ${ }^{14}$
} 


\section{The Origin and the Use of the Word Herpes}

he added two more, one of which is ' $H$. zoster' although he questions whether this should properly be distinguished from ' $\mathrm{H}$. periscelis' as a separate species. ${ }^{103}$ Linnaeus himself ${ }^{79}$ defines 'herpes' as a collection of crusted pustules on an 'erysipelatous base'. To Linnaeus 'erysipelas' merely meant a patch of erythema which healed with branny desquamation.

Vogel ${ }^{117}$ defines 'herpes' or 'serpigo' as 'papula ardens, cutem serpentibus minimis pustulis erodens'; but he adds, 'pupura scorbutica, quam vocant, verissima serpigo est'. Twelve years later, Sagar ${ }^{98}$ defines 'herpes' as 'papularum prurientium in squamas furfuraceas fatiscentium'. In the same class (Vitia) and order (Efflorescentia) he has 'phlycthaena', defined as 'vesicula parva fluido seroso plena, quae deinde sponte rumpitur et fundit serum'. Nevertheless he includes zoster as one of his nine species of 'herpes' and his 'herpes miliaris' would probably have included the modern herpes simplex. Sagar's ' $H$. Simplex', however, is far more likely to have been eczema or prurigo. Both Sagar's classification and that of Plenck, ${ }^{94}$ which was published the following year, are obviously based on the classification of de Sauvages. ${ }^{103}$

Cullen ${ }^{25,}{ }^{26}$ is closer to Turner than the other writers, although he has zoster as one of the two species in his genus 'erysipelas' ('E. phlyctaenodes'): Good $^{52}$ quotes Willan and Bateman and recognizes six varieties of 'herpes': H. miliaris, H. exedens, H. zoster, H. circinatus (or H. serpigo), H. iris, and H. localis (e.g., $\mathrm{H}$. labialis and $\mathrm{H}$. praeputialis).

To return from the nosologists to writers on dermatology, the next author after Turner who gives much attention to 'herpes' is Lorry. ${ }^{83}$ This author devotes no less than twelve quarto pages to discussing the views of his predecessors before he gives his own description:

solitaria vulgo nascitur una herpetis miliaris areola cute caeteroquin integra, limbo rubello distincta. Pustulae emicant vulgo sero repletae sub ipsa epidermide aggregatim compositae, interstitia replent lemae epidermidis quae areolam faciunt asperam. Inest major quam pro malo exoriri debere videretur cruciatus, sed mox et paucarum horarum intervallo subnascitur altera pustularum agglomeratio, quam aliae mox confertim adnatae per plurium dierum spatium excipiunt.

This certainly sounds as though it might be zoster.

His contemporary Plenck ${ }^{95}$ gives a somewhat different description: 'papularum chronicarum ichoroso-squamosarum semper ulterius serpentium agmen'. He has six species of 'herpes seu serpigo'. Hebra ${ }^{60}$ has attempted to determine the modern terms to which Plenck's species correspond: his suggestions are given in parentheses in the following list:

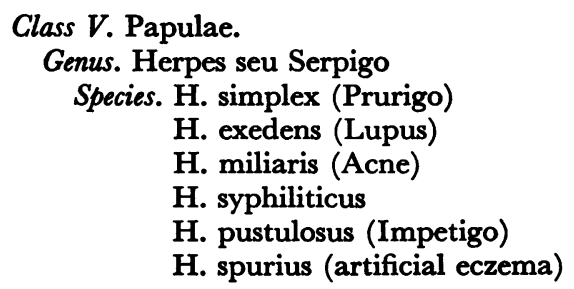




\title{
T. S. L. Beswick
}

\author{
Subspecies (of $\mathbf{H}$. spurius) \\ $\mathrm{H}$. periscelis \\ H. collaris \\ H. cerdonum \\ H. a tactu toxicodendron
}

Plenck places zoster in a separate class (Maculae) as a genus of which it is the only species. It is called 'zona seu zoster' and, we are told, is not to be confused with 'zona herpetica' which is a name given to $H$. collaris and $H$. periscelis. Fever-blisters are described under the name of 'miliaria febrilia' and placed in the genus 'Miliaria' of the class 'Vesiculae seu Phlyctenae'. In the first edition of his book, Doctrina de Morbis Cutaneis ${ }^{94}$ the classification is much the same except that zoster is in the class 'Vesiculae' and the naming of the various species of 'herpes' is slightly different.

We may conclude our account of the eighteenth century by referring briefly to Heberden and to Lettsom. Heberden ${ }^{56}$ regards 'shingles' and 'herpes' as synonyms: he gives a good account of herpes zoster, stressing particularly the occurrence of post-herpetic neuralgia. Lettsom, ${ }^{78}$ on the other hand, gives excellent accounts of pruritus ani and pruritus vulvae and makes no apology for calling both conditions 'herpes'.

The beginning of the nineteenth century saw the rise of two men, Robert Willan and Thomas Bateman, whose writings were to exert a profound influence on dermatology.

It is true that Willan's first serious contribution to dermatology, an essay for which he received the Fothergillian Gold Medal of the Medical Society of London in I 790, was written more than ten years before the close of the eighteenth century. ${ }^{82}$ However this essay was never published and it is improbable that Willan exerted much influence outside London until after 1800 . Until recently something of a mystery has surrounded the dermatological writings of Willan. As long ago as 1866 Hilton Fagge ${ }^{31}$ drew attention to the fact that, although his book, On Cutaneous Diseases, was not published until 1808 , Hebra ${ }^{57}$ cites a German 'translation' of 1799 . This ninety-year-old riddle has recently been solved by the discovery in the library of the Department of Pathology at Cambridge of an imperfect copy of an earlier English edition. ${ }^{15}$, ${ }^{107}$ Unfortunately Willan never lived to complete the second volume of his work, which was to have included the Order Vesiculae containing the genus Herpes. We have therefore, no full, first-hand account of Willan's views on the conditions which should be included in this genus, and must rely on a few scattered remarks in the first volume and on what we learn from the writings of his faithful disciple and colleague at the Carey Street Dispensary, Thomas Bateman.

In 18 i 3 Bateman published the first edition of his book, A Practical Synopsis of Cutaneous Diseases, according to the arrangement of Dr. Willan. This little book, although it contains but one plate, was deservedly popular and went through six editions in the next eleven years. I have used the third edition of $1814 .{ }^{12}$ In 18 i 7 Bateman published the first edition of a companion volume, illustrated by coloured plates and entitled Delineations of Cutaneous Diseases. ${ }^{13}$ Shortly after 


\section{The Origin and the Use of the Word Herpes}

Willan's death in 1812 Bateman had acquired all Willan's plates and a large amount of material intended by Willan for his second volume, as well as the copyright of his book On Cutaneous Diseases. The Delineations contained most of the plates included in Willan's book, some of them re-engraved, as well as a great many new ones.

Bateman ${ }^{12}$ recognized six species of the genus 'Herpes', all of which are characterized by one or more localized crops of small superficial vesicles on the skin which heal spontaneously within ten or twelve days. Healing cannot be accelerated by treatment, indeed injudicious applications may delay recovery. None of the species is infectious. His species are: $H$. phlyctaenodes, H. zoster, H. circinatus, $H$. labialis, $H$. praeputialis, and $H$. iris. The last was not included in the genus by Willan, and it was more than half a century before Bateman's mistake was recognized and erythema iris accorded its proper status as a variety of erythema multiforme. ${ }^{24},{ }^{39},{ }^{111}$ The ' $\mathrm{H}$. phlyctaenodes' of Bateman appears not to have been a single clinical entity. In his description of ' $\mathrm{H}$. zoster' he does not mention the occurrence of lesions on the face or limbs, and it seems probable that Bateman (and presumably Willan too) would have called zoster in these situations ' $\mathrm{H}$. phlyctaenodes': certainly his illustration of the latter condition looks exactly like zoster in the cutaneous distribution of the third, or second and third lumbar roots. ${ }^{13,}{ }^{62}$ However, he also mentions another variety of 'H. phlyctaenodes', which he calls the 'miliary variety'. In this, the vesicles are smaller and the condition may spread over almost the whole body. He gives noillustration of this second variety and its exact identity is a matter for conjecture.

Apart from his failure to recognize that it may occur elsewhere than on the trunk, his description of ' $\mathrm{H}$. zoster' is adequate. His ' $\mathrm{H}$. labialis' and ' $\mathrm{H}$. praeputialis' are the same as the varieties of herpes simplex designated by these terms today. Bateman's ' $H$. circinatus' appears to have been some variety of ringworm, although he denies this.

It might be argued that the reason why Willan's book made such an impact on dermatology was that he was the first author in this field to make extensive use of coloured plates. That this argument cannot be sustained, however, is clear from the fact that the far more lavishly and competently illustrated works of his contemporary Alibert, although much admired during his lifetime, are now regarded, even in his own country, as medical works of art rather than as serious contributions to the science of dermatology; whereas Willan, like Turner, has been acclaimed the 'Father of English Dermatology' and much that he wrote is still acceptable today.

Of Alibert's two systems of classifying skin diseases, the second is undoubtedly an improvement on the first. However Bateman ${ }^{12}$ is not far from the truth when he says 'The merit of his publication belongs principally to the artists, whom he has had the good fortune to employ' and: 'He has, moreover, thrown together his genera, without any attention to their affinity or disimilarity, making an arbitrary whole of disjointed parts.' Of the place of herpes in Alibert's first classification ${ }^{7}$ little need be said. As Bateman ${ }^{12}$ points out his 'definition' of the genus 'Les Dartres' is so wide and so vague that almost any skin disorder 


\section{T. S. L. Beswick}

could be included in one of its seven species. The second system of classification is better, although Alibert's views on the proper use of the word 'herpes' differ fundamentally from those of Willan and Bateman. Alibert ${ }^{8}$ says with some justification; 'l'etymologie révèle la juste signification'; certainly a tendency to 'creep' is not a striking feature of the conditions Willan designates 'herpes'. Alibert continues: 'le mot herpes ... est déjà consacré pour exprimer un genre de dermatoses rampantes, tellement réfractaires aux moyens de l'art que leur opiniâtreté, pour ainsi dire, passée en proverbe': this is more questionable. $\mathrm{He}$ collects together a most heterogeneous group of disorders to constitute his genus 'Herpes'. His 'species I', 'H. furfuraceus', is undoubtedly ringworm: his 'species II', 'H. squamosus', comprises seborrhoeic dermatitis, pruritus ani et pudenodorum, epidermophytosis of the groin, chronic scaly eczema, cheiropomphalyx, and acute exfoliative dermatitis. Those disorders which Willan and Bateman call 'herpes', he designates 'Olophlyctis', except herpes zoster which is placed in a genus of its own ('Zoster') with two species, 'Zoster acutus' and 'Zoster chronicus'. The latter differs from the former in that it is followed by postherpetic neuralgia. The species of the genus 'Olophlyctis' are: 'O. miliaire' (? ringworm), 'O. volatile' (infantile eczema), 'O. prolabiale' (herpes labialis), 'O. progeniale' (herpes genitalis), and 'O. hydroique' (hydroa).

For a time Alibert's works were much esteemed, but ultimately even his own pupil Biett came to use Willan's nomenclature in his lectures.

Another early-nineteenth-century writer on dermatology was Tilesius. ${ }^{113}$ It was after reading his paper on 'Herpes' that Willan decided to place the vesicular and bullous eruptions in separate genera. ${ }^{12}$ His views on 'herpes', however, are very different from Willan's. He recognizes two divisions of the genus 'Herpes', the vesicular and the papular. The former comprises the following species: ' $\mathrm{H}$. phlyctaenodes' (? herpes zoster), ' $\mathrm{H}$. erysipelatosus' (? erysipelas), and $\mathrm{H}$. miliaris (apparently some form of eczema).

Jaconelli, ${ }^{75}$ like Willan, regarded 'herpes' as a superficial vesicular eruption of the skin; but from his description it is clear that the principal condition he had in mind was eczema.

It will be apparent that even as late as the beginning of the nineteenth century opinion was very much divided as to the proper significance to be attached to the word 'herpes'. Willan's view that the term should be restricted to those conditions characterized by the appearance of localized groups of vesicles; a short, self-limiting course, and the absence of more than mild constitutional symptoms was destined to prevail. That it did so was probably due to the fact that it was embodied in a system of classification of skin diseases which was far in advance of its rivals, rather than because of the weight of ancient authority which Willan was able to adduce in its support. However victory was not won immediately: Alibert outlived Willan by twenty-five years: Cazenave ${ }^{18}$ introduced the term 'Herpes tonsurans' to describe ringworm of the scalp. This term was in use in human medicine at least as late as $188 \mathrm{I},{ }^{73}$ and veterinary surgeons still refer to certain types of animal ringworm as herpes. ${ }^{76}$ However most authorities accepted Willan's use of the word (see Hebra ${ }^{61}$ ). 


\section{The Origin and the Use of the Word Herpes}

'Herpes iris' was to remain a member of the genus 'Herpes' until the eighties of the nineteenth century when it was accorded its proper status as a variety of erythema multiforme; although Hebra ${ }^{65}$ had said twenty years before that he had been tempted to regard 'Herpes iris', 'Erythema iris', and 'Erythema multiforme' as variants of the same morbid process.

Of 'Herpes phlyctaenodes' we hear little after Hebra ${ }^{62}$ declined to recognize its existence as a separate entity.

Although the 'Herpes circinatus' of Willan and Bateman was probably ringworm, Hebra ${ }^{65}$ appropriated the term to describe a variant of 'Herpes iris'; after his time it gradually fell into disuse.

Finney ${ }^{33}$ and Pringle ${ }^{97}$ recognized but two species of herpes: herpes catarrhalis and herpes zoster. The latter divides herpes catarrhalis into two types: herpes facialis and herpes progenitalis.

Nevertheless, as pointed out by Bulkley ${ }^{17}$ herpes gestationis had been described by Gibert as early as $1840 .{ }^{50}$

Erasmus Wilson ${ }^{121}$ described two cases of the disease which he called 'herpes circinnatus bullosus'. Shortly afterwards Milton ${ }^{86}$ recorded a similar case to which he gave the same name. But when he repeated his account of this patient in his book ${ }^{87}$ he changed the name to 'herpes gestationis': this designation was adopted by Bulkley ${ }^{50}$ in his very full account of the disease.

Dermatitis herpetiformis was first described by Fox as hydroa in $1880^{38}$ and named four years later by Duhring ${ }^{28}$ in a classical paper.

In spite of general agreement that the use of the term 'herpes' should be restricted to herpes zoster and herpes febrilis (catarrhalis), various accounts appeared during the second half of the nineteenth century of cases of so-called herpes which were clearly neither of these two conditions. Examples are Dukes's account of a case of 'Acute general Herpes', ${ }^{29}$ Curgenven's cases of 'Herpes Contagiosus' ${ }^{27}$ and Sangster's case of 'abortive Herpes' which appears to have been a case of pityriasis rosea. ${ }^{100}$

In this necessarily brief historical review it has been quite impossible to notice all the authors who have used the word 'herpes' and no attempt has been made to list those who have written on skin diseases without making use of the term.

The only condition which has maintained its claim to the name 'herpes' during the greater part of the period reviewed and retains the name today is herpes zoster. Herpes labialis (febrilis) may have been known by the name of 'herpes' by Hippocrates, but it certainly was not the principal condition he so designated. The first author to give a clear account of herpes febrilis under the name of 'herpes' was Richard Morton in $1694 .{ }^{88}$ The present-day use of the word is essentially that of Daniel Turner ${ }^{115}$ and of Robert Willan, ${ }^{12}$ although both of these authors admitted certain varieties of cutaneous ringworm to the genus 'Herpes' which we exclude.

The validity of the term 'herpes gestationis' is questionable. The disease differs from dermatitis herpetiformis only in its association with pregnancy: the histological changes are identical in the two conditions, as are the subjective symptoms and the appearance and distribution of the eruption. However 


\section{T. S. L. Beswick}

the term has been hallowed by time and will, no doubt, continue to be employed.

The term 'dermatitis herpetiformis' itself is less objectionable, and until more is known of its aetiology, there would be little point in trying to substitute any other name.

The recognition of the common aetiology of herpes facialis, herpes labialis, herpes febrilis, and herpes genitalis, has led to the relegation of these terms to a purely descriptive role as different clinical manifestations of one disease, herpes simplex. Now that it has become clear that the same virus can cause lesions in the mouth, eye, oesophagus, and internal organs, it is only reasonable to extend the term 'herpes simplex' to include these less common, non-cutaneous manifestations of the infection as well.

\section{REFERENCES}

I. Agtuarius. Opera. Paris, I556. Pt. II, Bk. ii, Ch. 12, pp. 146 and 307.

2. Adams, F. The Seven Books of Paulus Aegineta. Tr. F. Adams. 3 vols. Sydenham Society., London, 1844-8. Vol. II, pp. 62-5.

3. Aemilius Mager. 'De Herbis' text in Medici Antiqui omnes, qui Latinis literis Ëc. Venice, 1547, p. $227 b$.

4. Ibid., p. $232 b$.

5. Aetrus of Amida. Tetrabiblon. Ed. Ioh. Cornarius, Basle, I542. Serm. II, Bk. I, Ch. 129, p. 259. (This is a Latin translation.)

6. Ibid. Serm. IV, Bk. 2, Ch. 6o, p. 805.

7. Alibert, J. L. Précis théorique et pratique des Maladies de la Peau, 2 vols. Paris, I810.

8. Clinique de l'Hôpital Saint Louis ou Traité complet des Maladies de la Peau. Paris, 1833 .

9. Avigenna. Canon Medicinae. Tr. Gerardus Cremonensis (Latin), Bk. IV, Feu iii, Tr. I, Ch. 9, 3 vols. Venice, i6o8. Vol. II, p. I 44 .

Io. Bail la r g e R, J. Mémoire sur l'oblitération de canal de Sténon. Gaz. méd., Paris, I 853, 3rd series, 8, 194 .

II. Bärens PRUNG, F. W. von. Die Gürtelkrankeit. Berlin, I86I, p. 2 I.

12. B A te man, T. A Practical Synopsis of Cutaneous Diseases. 3 rd edition. London, 1814.

13. - Delineations of Cutaneous Diseases. London, 18 I 7.

14. B E R G, F. Linné et Sauvages: les rapports entre leurs Systèmes Nosologique. Lychnos, p. 37 .

I5. Beswick, T. S. L. Robert Willan: the solution of a ninety-year-old mystery, 7. Hist. Med., 1957, 12, 349 .

I6. Boe Rh AAve, H. Aphorisms, with commentaries by Baron van Swieten, English translation, I 7 vols., Edinburgh, I 776. No. 1484. Vol. xvII, pp. 355-6r.

17. BULKLEY, L. D. On Herpes Gestationis: a rare affection of the skin peculiar to Pregnancy. Amer. F. Obstet. Dis. Women Child., 1874, 6, 580.

18. Gazenave, A. Traité des Maladies du Cuir Chevelu. Paris, 1850, p. 190.

19. Gelsus, A. De Re Medicina, Latin text of Marx (1915), English translation, W. G Spencer. Loeb Classical Library, London, 1935. Bk. V, Ch. 28, Sec. 4, pp. $134-7$. 
20. Ibid. Bk. VI, Ch. I I, Sect. 3, pp. 256-7.

21. Ghauliac, Guy de. Chirurgia Magna. 1363. Tr. and Ed. E. Nicaise. Paris, 189o. Tr. II, Doct. i, Ch. 2, Sect. 2, p. 98.

22. Ibid. Ch. 3, Sect. I, p. Io6.

23. Constantinus A f r icanus. De Communibus Medico cognitu necessariis locis. Basle, I539. Vol. vII, p. I4 (see Migne, J. P., Patrologiae cursus completus. Paris, I 854 . Vol. GL, cols. I 559-1666. Cited by Willan, R., I 821 , q.v.).

24. Crocker, H. R. Cases of Erythema or Herpes Iris. Trans. clin. Soc. Lond., I88I, I4, I 33 .

25. Gullen, W. Synopsis Nosologiae Methodicae, Edinburgh, i 769. (This edition includes the systems of de Sauvages, Linnaeus, Vogel, and Cullen himself: the individual species are not listed, but only the orders and genera.)

26. Ibid. Edinburgh, I813. (This edition includes the systems of Sagar and Macbride as well as those included in the earlier edition. Cullens's own system is given in full.)

27. Gurgenven, J. B. Cases of Herpes Contagiosus. Brit. med. F., r 869, 2, 488.

28. Duhring, L. A. Dermatitis Herpetiformis. 7. Amer. med. Ass., 1884., 3, 225.

29. Dukes, C. Acute general Herpes. Lancet, 1876, 2, 884.

30. F A в E R, K. Nosography in Modern Internal Medicine. New York, 1923, pp. 20-6.

31. F A G E, H. Translator's preface to On Diseases of the Skin, F. Hebra, New Sydenham Society, London, I866. Vol. I, p. viii.

32. Ferne L, J. Universa Medicina. I554. Ed. I. and O. Heurnius. Utrecht, I656; Bk. VII, Pathologiae, Ch. 4, p. 288.

33. Finney, J. M. A Clinical Lecture on Herpes. Med. Press Circ., I88ı., n.s. 3r, 222, 333.

34. Föes, A. Magni Hippocratis Medicorum omnium facile principis opera quae extant. Geneva, 1657 , p. 98.

35. Ibid., p. 220.

36. Ibid., pp. 1023-4.

37. Forestus, P. Observationum et Curationum Medicinalium. Leyden, 1606. Bk. XXXII, De lue venerea, pp. I64, 272.

38. Fox, T. (Ed.) A clinical study on Hydroa. Arch. Dermatol., I88o, 6, 16.

39. - On the herpes iris of Bateman. Lancet, $1881, \mathbf{r}, 615$.

40. FreIND, J. The History of Physick, 2nd edition, 2 vols. London, 1 725-7. Vol. I, pp. $287-94$.

41. GALEN, De tumoribus praeter naturam. Greek text and Latin translation of

C. G. Kühn, 20 vols. Leipzig, I821-33. Vol. vII, p. 722.

42. De morborum differentiis. Kühn. Vol. vi, p. 874.

43. —De symptomatum differentiis. Kühn. Vol. vir, p. 75.

44. - De inaequali intemperie. Kühn. Vol. vII, p. 751 .

45. —De methodo medendi, Bk. II. Kühn. Vol. x, p. 83 .

46. — Ibid., Bk. XIV. Kühn. Vol. x, p. I005.

47. - Ad Glauconem de medendi methodo, Bk. II. Kühn. Vol. xI, p. 74 .

48. — In Hippocratem de alimento, Bk. III. Kühn. Vol. xv, p. $34^{2}$.

49. Definitiones medicae, No. 347. Kühn. Vol. xIx, p. 440.

50. GiberT, C. M. Cited by Bulkley, I874, q.v.

51. Good, J. M. A Physiological System of Nosology. London, 1817, pp. 478-81 (footnote).

52. Ibid., pp. $476-83$. 


\section{T.S. L. Beswick}

53. Gorraeus, I. Definitionum Medicarum. 24 books in one volume. Paris, 1564 .

54. Guthrie, D. A History of Medicine. London, 1945, p. 72.

55. Hal y A в B As. Works (Latin). Ed. Michael de Capella. Lyons, I 523, p. 93.

56. He Be R DEN, W. ( 1784 and 1816 ). Commentaries on the History and Cure of Diseases.

Latin edition. Frankfurt, I 784, p. 99. English edition, London, 1816, p. I05.

57. He B RA, F. On Diseases of the Skin. English edition, I866. Vol. I, Tr. Fagge, C. H., New Sydenham Society, London, p. I5.

58. Ibid., p. 359 .

59. Ibid., p. 360.

6o. Ibid., p. 36 I.

6r. Ibid., p. 363 .

62. Ibid., pp. $3^{67}-8$.

63. Ibid., p. 369 .

64. Ibid., p. 370.

65. Ibid., p. 379.

66. Hildanus, F. (1606-46). Opera Omnia. Frankfurt-on-Main, 1646. 'Observationes Chirurgica', Cent. I, Obs. xcix, p. 74 .

67. Hippogrates. Epidemics III, Sect. iii, Eivores complètes d'Hippocrate. Greek text with French translation, by Littré, E., Io vols. Paris, 1839-6r. Vol. III, p. 85 .

68. - Aphorisms V, No. 22. Littré. Vol. Iv, p. 540.

69. - Epidemics VI. Littré. Vol. v, p. 353.

7o. - Coan Prognostications. Littré. Vol. v, p. 729.

71. - The Use of Liquids. Littré. Vol. vi, p. I 35.

72. — Prorrhetics II. Littré. Vol. IX, p. 37.

73. Hirsch, A. Handbook of Geographical and Historical Pathology. Tr. from the 2nd German edition by Creighton, C., 3 vols. New Sydenham Society, London, 1883-6. Vol. II, pp. 378-9.

74. Hoffmann, F. Opera Omnia Physico-Medica. 6 vols. Geneva, I 784. Vol. III, pp. 426 et seq.

75. JAGONELLI, K. On Herpes. Edinb. med. surg. F., 1806, 2, 325. (Article signed ' $\mathrm{K}$ '.)

76. Kelser, R. A. and Schoening, H. W. Veterinary Bacteriology. 4th edition. Baltimore, 1943, p. 423.

77. LANGENSKIÖLD, A. Gustatory local hyperhidrosis following injuries in the parotid region. Acta. chir. Scand., 1946, 93, 294.

78. Letrsom, J. C. Observations on certain Herpetic Affections attended with painful irritations. Mem. Med. Soc. Lond., I 792, 3, 346. (Read before the Society 3I December I 787.)

79. Linnaeus, G. Genera Morborum. Uppsala, i 763.

8o. LitTre, E. Euvres complètes d'Hippocrate. Greek text with French translation, Io vols. Paris, 1839-6r. Vol. v, p. 106.

81. Ibid., p. 108.

82. London, Medical Society of. Entries in the Minutes of the Society between 4 January and 6 February 1790 . (Unpublished.)

83. Lorry, A.-C. Tractatus de Morbis Cutaneis. Paris, 1777, pp. 294-384.

84. Lugretius. De Rerum Natura. Bk. VI, lines 658-64. In the Teubner edition, Ed. J. Martin. Leipzig, 1934.

85. MAJOR, R. H. History of Medicine. 2 vols. Oxford, i954. Vol. II, p. 565. 


\section{The Origin and the Use of the Word Herpes}

86. Milton, J. L. On certain unusual forms of Vesicular Eruption. 7. cutan. Med. Dis. Skin. London, $1867, \mathbf{r}, 31$ r.

87. - The Pathology and Treatment of Diseases of the Skin. London, 1872, p. 205.

88. Morton, R. Pyretologia, pars Altera. London, 1694, pp. I5, 16.

89. Oribasius. Complete extant works. Greek text with French translation, Daremberg, C., and Bussemaker, U. C., 6 vols. Paris, I85I-76. Vol. III, pp. 655 et seq.

9o. PAGE, D. L. Personal communication, I955.

91. PAGE L, J. L. Geschichte der Medizin. 2 vols. Berlin, 1898. Vol. I, p. 323.

92. PARE, A. Dix livres de la Chirurgie. ${ }^{564}$. Bk. V, Ch. xiii. Ed. Malgaigne, J.-F., 3 vols. Paris, 1840-1. Vol. I, p. 340 .

93. Paulus Aegineta. The Seven Books of Paulus Aegineta. Tr. Adams, F., 3 vols. Sydenham Society, London, 1844-8. Vol. In, pp. 6r-2.

94. Plenck, J. J. Doctrina de Morbis Cutaneis. German edition. Warsaw, 1777.

95. Ibid. Latin, and edition. Vienna, 1783 .

96. Pliny (the Elder). Natural History. Tr. Bostock, J., and Riley, H.T., 6 vols. London, 1855-7. Vol. v, p. 199.

97. Pringle, J. J. Article on 'Herpes' in A Dictionary of Practical Medicine. Ed. Fowler, J. K. London, I 89o, p. 344 .

98. S A G A R, J. B. M. Systema Morborum Symptomaticum. Vienna, I 776.

99. Saligeto, William of. Chirurgia. 1275. Tr. (French), Pifteau, P. Toulouse, I898. Bk. I, Ch. 58, pp. I68-9.

Ioo. Sangster, A. A case of abortive Herpes. Trans. clin. Soc. Lond., I878, I1, 212.

ror. Sauva ges, F. B. De. Traité des Classes des Maladies. Avignon, 1731 .

102. -Nosologia Methodica sistens Morborum Classes. I 764. 5 vols. Amsterdam, I 763 . Vol. II, pp. I6-20.

103. ——Nosologia Methodica sistens Morborum Classes. 2 vols. Amsterdam, I 768 . Vol. I, pp. I32-4.

104. Scribonius Largus. Compositiones Medicae. Ed. I. Rhodius. Padua, 1655, p. I30.

105. Senega. Oedipus, Act I, lines r9o-3. In the Teubner edition. Ed. G. Richter. Leipzig, 1902.

106. Sennert, D. Practicae Medicinae. 1652. 2nd edition, 6 vols. Wittenberg, 1636-54. Vol. v, Part i, Ch. I 7, p. 91.

107. Suthe rland, F. M. Willan's Cutaneous Diseases. F. Hist. Med., 1958, 13, 92.

108. Swieten, G. L. B. van. See Boerhaave, H., I 776.

I09. Sylvest, O. Herpes Labialis as a complication of medical diseases, with particular reference to the prognosis of Pneumonia. Acta med. Scand., 1952, I4r, 385 .

I 1 0. TARGA, L. I have used the version of Targa's text of Celsus' De Medicina, I 769, published by Adam Dickinson, Edinburgh, I 8 r 4 .

I I I. TAylor, F. Cases of Erythema and Herpes Iris. Trans. clin. Soc. Lond., I88I, I4, 138.

I12. Theodoric Borgognoni (Bishop of Cervia). Chyrurgia. c. 1266. Bk. iii, Ch. 16.

I 13. Tilesius, W. G. On Herpetic Eruptions, Pt. I, Tr. from the Paradoxien (1804) of F. H. Martens, Leipzig, I802, by T. M. Winterbottom and abridged by T. Bateman. Med. Phys. F., Lond., 1804, 11, 230.

I14. Tulp, N. Observationum Medicarum. Amsterdam, I64I, Bk. III, Ch. 44, pp. 255-6. 


\section{T. S. L. Beswick}

II5. Turner, D. A Treatise of Diseases incident to Skin. London, I 7I4, pp. 48-55.

II6. VIRGIL. Georgics. Bk. III. In the Teubner edition. Ed. G. Ianell. Leipzig, 1930, p. 77.

I 7. Voge L, R. A. Definitiones Generum Morborum. Göttingen, I 764 .

I 8. Willan, R. On Cutaneous Diseases. London, r8o8, p. vi.

I19. - Miscellaneous Works. Ed. Ashby Smith, London, I82 I, pp. 52-3.

120. Ibid., p. 85 .

I21. Wilson, E. On Diseases of the Skin. London, I867, p. 294. 